\title{
Insights into interventions in managing COPD patients: lessons from the TORCH and UPLIFT ${ }^{\circledR}$ studies
}

REVIEW

\author{
Marc Miravitlles' \\ Antonio Anzueto ${ }^{2}$ \\ 'Fundació Clínic, Institut \\ d'Investigacions Biomèdiques August \\ $\mathrm{Pi}$ i Sunyer (IDIBAPS), Hospital Clinic, \\ Barcelona, Spain; ${ }^{2}$ Department of \\ Pulmonary/Critical Care, \\ The University of Texas Health \\ Science Center at San Antonio and \\ the South Texas Veterans Health Care \\ System, San Antonio, Texas, USA
}

This article was published in the following Dove Press journal: International Journal of COPD 7 May 2009

Number of times this article has been viewed
Correspondence: Marc Miravitlles Servei de Pneumologia, Hospital Clinic, Villarroel 170, 08036 Barcelona, Spain Tel +34 (93) 2275549

$\mathrm{Fax}+34$ (93) 2279813

Email marcm@clinic.ub.es

\begin{abstract}
Influencing the progression of COPD has long been an elusive goal of drug therapy. Directly or indirectly, this has again been investigated in two of the largest, long-term drug trials in COPD: Towards a Revolution in COPD Health (TORCH) and Understanding Potential Long-Term Impacts on Function with Tiotropium (UPLIFT ${ }^{\circledR}$ ). Neither trial achieved statistical significance in their respective primary outcomes; however, both make considerable contributions to understanding of how the progression of COPD may be influenced. The objective of this article is to review the data from these different trials with a view to what can be learnt about the management of COPD. The long-term improvements in lung function, health-related quality of life, and possibly survival from the use of long-acting bronchodilators in these trials suggest an influence on progression of the disease. With the more optimistic view of benefits from drug treatment of COPD that these trials provide, a review of prescribing practices is warranted.
\end{abstract}

Keywords: bronchodilators, $\mathrm{FEV}_{1}$, fluticasone, inhaled corticosteroids, mortality, salmeterol, tiotropium

\section{Burden of COPD}

Chronic obstructive pulmonary disease (COPD) is a major cause of morbidity and mortality, and represents a substantial economic and social burden worldwide. Global prevalence of COPD in the general population has been reported to be between $7.5 \%$ and $10 \%,{ }^{1,2}$ and is predominantly associated with smoking. In a meta-analysis of 67 population-based studies (representing $>111,000$ cases of COPD from 28 countries), prevalence of COPD was significantly higher among smokers (15.4\%) and ex-smokers $(10.7 \%)$ than people who had never smoked $(4.3 \%) .{ }^{2}$ Prevalence of COPD is therefore highest in countries where cigarette smoking is common.

Current prevalence data are likely to underestimate the true burden of COPD, since the disease is frequently misdiagnosed or not diagnosed until symptoms become clinically apparent at a more advanced stage. Of the people with COPD in Spain, for example, only an estimated $20 \%$ have their disease diagnosed. ${ }^{3}$ In the US, it is believed that between $60 \%$ and $70 \%$ of patients with reduced forced expiratory volume in 1 second $\left(\mathrm{FEV}_{1}\right)$ have never been diagnosed with COPD. ${ }^{4}$

The burden of morbidity and mortality due to COPD is predicted to increase. ${ }^{4}$ COPD is the fourth leading cause of mortality in the US and Europe, ${ }^{5}$ and approximately 2.7 million deaths worldwide were attributable to COPD in 2000. ${ }^{4}$ Age-adjusted mortality due to COPD doubled between 1970 and 2002 in the US, ${ }^{6}$ and total deaths from COPD are projected to increase by more than $30 \%$ in the next 10 years, ${ }^{7}$ with notable increases predicted in women. ${ }^{4}$ 
It is unsurprising, therefore, that the economic costs attributed to COPD are substantial. For example, mean annual direct costs of COPD under usual clinical practice in Spain were calculated in a prospective study to be US\$1876 per patient in 2003 (nearer US\$3000 for severe COPD), ${ }^{8}$ which is approximately twice the equivalent cost reported for asthma. ${ }^{9}$ In the UK, direct costs were estimated to equate to approximately US\$1900 per person per year in 1996, whilst in the US in the late 1990s, the annual cost of COPD was estimated to be US\$23.9 billion, equating to approximately US\$1500 per patient per year. ${ }^{10}$

\section{Evolution of the disease}

The Global Initiative for Chronic Obstructive Lung Disease (GOLD) and American Thoracic Society (ATS)/European Respiratory Society (ERS) consensus statements both define COPD as a progressive airflow limitation that is not fully reversible and recommend spirometry, particularly $\mathrm{FEV}_{1}$, as a means of diagnosing and staging COPD. Airflow limitation causes air trapping and hyperinflation as ventilation rate increases, for example during physical effort. ${ }^{11}$ Hyperinflation causes or worsens breathlessness, as breathing becomes inefficient. Breathlessness encourages inactivity due to avoidance of exertion. Exercise capacity becomes reduced and deconditioning increases, which further worsens breathlessness on activity, and the cycle continues. Collectively, this contributes to reducing the patients' health-related quality of life (HRQL). Exacerbations of COPD also contribute to worsen these disease outcomes. Currently, there is no universal definition of an exacerbation, though GOLD define an exacerbation as "an event in the natural course of the disease characterized by a change in the patient's baseline dyspnea, cough and/or sputum that is beyond the normal day-to-day variations, is acute in onset, and my warrant a change in regular medication in a patient with underlying COPD." 12

\section{FEV, decline as an outcome parameter}

$\mathrm{FEV}_{1}$ decline has been considered a parameter of disease progression. $\mathrm{FEV}_{1}$ as a parameter of disease in individual patients has considerable advantages in that it is relatively simple to measure (with appropriate training) and is prognostic of mortality, both as a single measure ${ }^{13-15}$ and in terms of the rate of decline. ${ }^{16}$

An increased rate of decline in $\mathrm{FEV}_{1}$ in susceptible smokers has been known for over 30 years, ${ }^{17}$ as has the fact that smoking cessation, provided it is achieved sufficiently early, reduces the rate of decline, though does not restore the $\mathrm{FEV}_{1}$ lost. ${ }^{18-21}$

However, information gained on the disease from measurement of $\mathrm{FEV}_{1}$ does have limitations. $\mathrm{FEV}_{1}$ does not correlate well with other markers of disease progression that are also prognostic of mortality, ${ }^{22}$ which question whether decline in $\mathrm{FEV}_{1}$ is the best marker of disease progression. ${ }^{23,24}$ Additionally, little is understood about the course through which $\mathrm{FEV}_{1}$ declines, which is unlikely to be linear, ${ }^{25}$ but could be graduated and variable depending on COPD exacerbations and comorbidities. ${ }^{26}$ Varying standards of spirometry and inter-patient variability adds to the challenge of comparing treatment groups with respect to the rate of decline in $\mathrm{FEV}_{1}$.

\section{Past studies that evaluated FEV, decline}

Numerous specifically designed trials have failed to show an effect of pharmacotherapy on the rate of decline in $\mathrm{FEV}_{1}$, including short-acting anticholinergic (ipratropium), ${ }^{18}$ an antioxidant (N-acetylcysteine), ${ }^{27}$ and inhaled corticosteroids. ${ }^{28-31}$ Two meta-analyses on the effects of inhaled corticosteroids (ICS) have contradicted each other, ${ }^{32,33}$ and a pooled analysis suggests that ICS do not have efficacy in reducing the rate of decline in $\mathrm{FEV}_{1}{ }^{34}$

In addition, regular physical activity has been suggested to reduce the rate of decline in $\mathrm{FEV}_{1}$ in smokers from a population study, ${ }^{35}$ however, this needs to be investigated in a prospective, controlled trial.

\section{Rationale for current disease modification studies (TORCH and UPLIFT ${ }^{\circledR}$ )}

A post-hoc analysis of 1-year data from two, double-blind, randomized, placebo-controlled trials, indicated that the longacting anticholinergic drug, tiotropium, may reduce the rate of decline in $\mathrm{FEV}_{1}$ in COPD patients. ${ }^{36}$ In addition, two retrospective analyses (representing over 9700 COPD patients) have suggested that use of ICS, either as monotherapy or in combination with a long-acting $\beta_{2}$-agonist (LABA), may reduce all-cause mortality in patients with COPD. ${ }^{37,38}$ Longerterm trials were required to further investigate these effects: specifically an effect of LABA/ICS on all-cause mortality and of tiotropium on the rate of decline in $\mathrm{FEV}_{1}$.

The Towards a Revolution in COPD Health (TORCH) trial was a 3-year, double-blind, parallel-group, placebocontrolled study of 6184 COPD patients randomized to salmeterol and fluticasone propionate, either as monotherapy 
or in combination. Primary outcome was all-cause mortality over 3 years, ${ }^{39}$ with a post-hoc analysis on the rate of decline in $\mathrm{FEV}_{1 .}{ }^{40}$

The Understanding Potential Long-term Impacts on Function and Tiotropium (UPLIFT ${ }^{\circledR}$ ) trial was a 4-year, randomized, double-blind, placebo-controlled, parallelgroup study involving 5993 patients with moderate-tosevere COPD randomized to receive either tiotropium or placebo. These patients continued to receive their otherwise usual bronchodilator therapy. The primary outcome of the UPLIFT $^{\circledR}$ study was rate of decline in $\mathrm{FEV}_{1}$ over 4 years. ${ }^{41}$

\section{Summary of key findings from TORCH and UPLIFT ${ }^{\circledR}$ TORCH}

TORCH did not achieve a significant decrease in mortality among patients treated with LABA-ICS combination therapy versus short-acting bronchodilators (placebo) (hazard ratio [HR] 0.825, 95\% confidence interval [CI], 0.681-1.002; $\mathrm{p}=0.052) .{ }^{42}$ However, active treatments significantly reduced the annual rate of exacerbations compared with placebo $(p<0.001)$ and exacerbations requiring hospital admission were reduced with the combination therapy and salmeterol alone compared with placebo ( $\mathrm{p} \leq 0.03$ ). The combination therapy also improved average HRQL compared with placebo and monotherapies over the 3-year trial period. Adverse event data from TORCH indicated an increased incidence of pneumonia among patients receiving ICS treatment, both as a combination treatment and as monotherapy. The treatment arms containing ICS had 439 deaths compared with 436 deaths in the non-ICS-containing arms.

Sustained increase in lung function was observed in all active groups compared with placebo. ${ }^{42} \mathrm{~A}$ post-hoc analysis (stated as being planned before unblinding) on rate of decline in postbronchodilator $\mathrm{FEV}_{1}$ showed an effect of the active treatment groups compared with placebo. ${ }^{40}$ The rate of FEV decline was $55 \mathrm{~mL} /$ year in the placebo (short-acting bronchodilators) group. In comparison, the rates of decline in the active treatment groups were significantly less $(p \leq 0.03)$ at $39 \mathrm{~mL} /$ year for combined therapy and $42 \mathrm{~mL} /$ year for ICS and LABA monotherapy. The rates of decline were similar between the active treatment groups, with no significant benefit of the combination over the individual components.

\section{$\mathrm{UPLIFT}^{\circledR}$}

$\mathrm{UPLIFT}^{\circledR}$ reported on moderate to severe COPD patients that received usual treatment (including LABA, ICS alone or in combination), and were randomized to tiotropium or placebo (control). These data did not show significant differences in the rate of decline in lung function or HRQL score between the tiotropium and control groups, but achieved a sustained increase in lung function and HRQL over 4 years $(p<0.001) .{ }^{43}$ Rate of postbronchodilator FEV 1 decline was $40 \mathrm{~mL} /$ year for tiotropium and $42 \mathrm{~mL} /$ year for the control group. At the end of the 4-year treatment period, the tiotropium group had not yet reached the level of impaired HRQL documented at baseline. Further, statistical significant increase in the proportion of patients achieving the reported minimal clinically significant difference of at least 4 units $(p<0.001)$ occurred in the tiotropium group compared with the control group.

UPLIFT $^{\circledR}$ demonstrated a significant reduction in the risk of having an exacerbation and an exacerbation leading to a hospitalization in the tiotropium group. Survival was significantly increased while patients received tiotropium and when including the follow-up of prematurely discontinued patients for the protocol-defined treatment period. However, the improvement in survival lost statistical significance when the 30-day, protocol-defined washout period was included. Additionally, overall cardiac and respiratory morbidity was reduced.

\section{Comparison of designs}

As expected for trials with different primary objectives, considerable differences exist between the TORCH and UPLIFT $^{\circledR}$ trial designs and entry criteria (Table 1). Aside from the different primary and secondary outcomes and treatment durations, a key difference is the medications that were permitted during the trials, other than the study drugs. ${ }^{39,41}$ TORCH permitted maintenance use of short-acting bronchodilators and short courses (eg, 10 days) of oral corticosteroids for the treatment of exacerbations..$^{42}$ Excluded were long-term use of oral corticosteroids, maintenance use of tiotropium (which was unavailable at the onset of the trial), and LABA and ICS, other than the study drugs. ${ }^{39,42}$ Hence, patients in the placebo (maintenance with short-acting bronchodilators) group of TORCH did not receive appropriate maintenance treatment according to the GOLD guidelines, ${ }^{44}$ which should include long-acting bronchodilators. This treatment group cannot, therefore, be considered as "standard" or "usual" care. Indeed, in part due to the positive outcomes of TORCH, this type of long-term, inappropriately-treated "placebo" comparison would no longer be considered ethical.

The UPLIFT ${ }^{\circledR}$ study permitted use of ICS, LABA, and their combination, but excluded inhaled anticholinergics. 
Table I Study designs

\begin{tabular}{|c|c|c|}
\hline & UPLIFT $^{\circledR}$ & TORCH \\
\hline Duration (years) & 4 & 3 \\
\hline Number of randomized patients & 5993 & 6112 \\
\hline Primary endpoint & Decline in lung function & All-cause mortality \\
\hline \multirow[t]{3}{*}{ Secondary endpoints } & Decline in SGRQ score & Exacerbations \\
\hline & Exacerbations & SGRQ score \\
\hline & Mortality & \\
\hline Run-in phase & $\begin{array}{l}\text { Continue therapy and adaptation (except } \\
\text { inhaled anticholinergics) }\end{array}$ & Withdrawal (ie, ICS, LABA and tiotropium) \\
\hline \multirow{2}{*}{$\begin{array}{l}\text { Nonpermitted respiratory } \\
\text { medications }\end{array}$} & Other inhaled anticholinergics & Other ICS \\
\hline & & $\begin{array}{l}\text { Other LABA } \\
\text { Long-term use of oral corticosteroids } \\
\text { Tiotropium (unavailable at onset of trial, } \\
\text { excluded throughout) }\end{array}$ \\
\hline \multirow[t]{3}{*}{ Frequency of control visits } & General: 3 months (+ first month) & General: 3 months \\
\hline & Lung function: 6 months (+ first month) & Lung function: 6 months \\
\hline & SGRQ: 6 months & SGRQ: 6 months \\
\hline \multirow[t]{2}{*}{ Reversibility test } & $\begin{array}{l}80 \mu \mathrm{g} \text { ipratropium bromide plus } 400 \mu \mathrm{g} \\
\text { salbutamol }\end{array}$ & $400 \mu g$ salbutamol \\
\hline & No exclusion due to reversibility & Exclusion of patients with $>10 \%$ reversibility \\
\hline \multirow[t]{3}{*}{ Quality assurance of spirometry } & Standardized equipment & Office-based spirometry \\
\hline & External quality assurance & No additional quality assurance \\
\hline & External, blinded reading & \\
\hline \multirow[t]{6}{*}{ Evaluation of mortality } & Vital status to 4 years & Vital status to 3 years \\
\hline & Vital status to $4+$ years & COPD-related mortality to 3 years \\
\hline & Lower respiratory-related mortality & On-treatment mortality \\
\hline & Cardiac-related mortality & $\begin{array}{l}\text { Primary COD and relationship with COPD } \\
\text { determined by independent committee }\end{array}$ \\
\hline & On-treatment mortality & Two interim safety analyses \\
\hline & $\begin{array}{l}\text { Primary COD determined by } \\
\text { independent committee }\end{array}$ & \\
\hline Definition of exacerbation & $\begin{array}{l}\text { An increase in, or new onset of, more } \\
\text { than one respiratory symptom (cough, } \\
\text { sputum, sputum purulence, wheezing, } \\
\text { or dyspnea) lasting } 3 \text { days or more and } \\
\text { requiring treatment with an antibiotic } \\
\text { or a systemic corticosteroid }\end{array}$ & $\begin{array}{l}\text { A symptomatic deterioration requiring } \\
\text { treatment with antibiotic agents, systemic } \\
\text { corticosteroids, hospitalization, or a combi- } \\
\text { nation of these }\end{array}$ \\
\hline \multirow[t]{6}{*}{ Inclusion criteria } & $\begin{array}{l}\text { Outpatient with clinical diagnosis } \\
\text { of COPD }\end{array}$ & Diagnosis of COPD \\
\hline & Age $\geq 40$ years & Age $40-80$ years \\
\hline & Smoking history $\geq 10$ pack-years & Smoking history $\geq 10$ pack-years \\
\hline & $\begin{array}{l}\text { Postbronchodilator }{ }^{\mathrm{a}} \mathrm{FEV}, \leq 70 \% \\
\text { predicted }^{\mathrm{b}}\end{array}$ & Prebronchodilator $\mathrm{FEV}, \leq 60 \%$ predicted $^{\mathrm{b}}$ \\
\hline & Postbronchodilator $^{\mathrm{a}} \mathrm{FEV} / \mathrm{FVC} \leq 70 \%$ & Prebronchodilator $\mathrm{FEV} / \mathrm{FVC} \leq 70 \%$ \\
\hline & & $\begin{array}{l}\text { Postbronchodilator }{ }^{c} \mathrm{FEV}_{\text {, increase }}<10 \% \\
\text { of predicted value }^{\mathrm{b}}\end{array}$ \\
\hline Exclusion critera & $\begin{array}{l}\text { Asthma or a coexisting illness that could } \\
\text { preclude participation in the study } \\
\text { or interfere with the study results }\end{array}$ & $\begin{array}{l}\text { Asthma, non-COPD respiratory disorders, or } \\
\text { other condition likely to interfere with the } \\
\text { study or cause death within } 3 \text { years }\end{array}$ \\
\hline
\end{tabular}




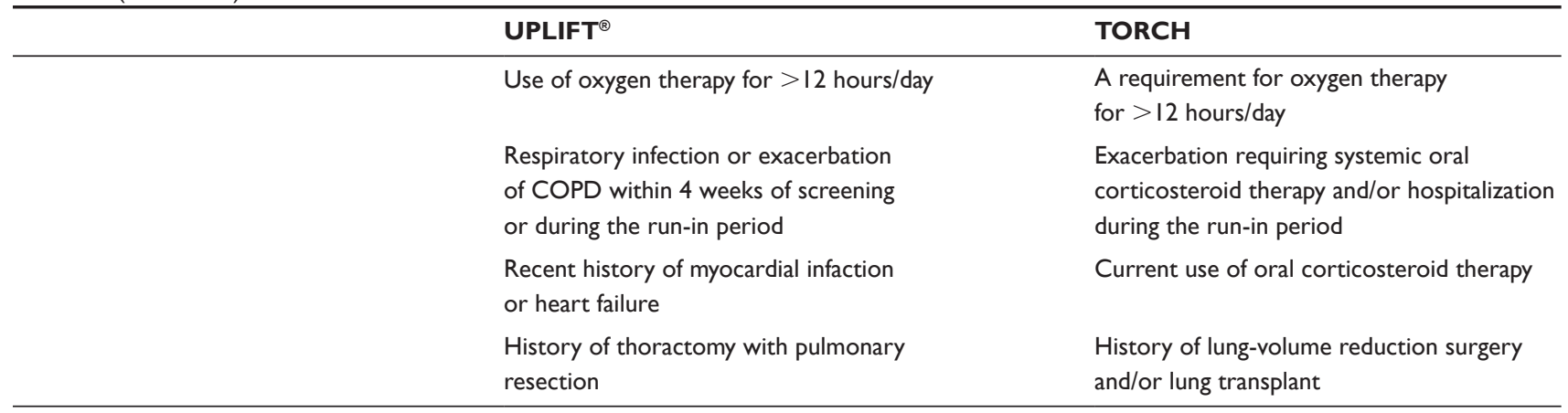

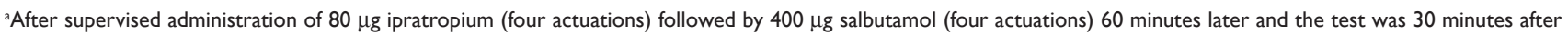

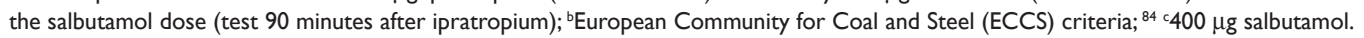

Abbreviations: $\mathrm{FEV}_{1}$, forced expiratory volume in I second; FVC, forced vital capacity; ICS, inhaled corticosteroids; LABA, long-acting $\beta_{2}$-agonists; SGRQ, St. George's Respiratory Questionnaire; COD, cause of death.

No restrictions were imposed for medications prescribed to treat exacerbations. Hence, UPLIFT ${ }^{\circledR}$ closely represented "usual" COPD care as underlying therapy, other than inhaled anticholinergics, regardless of whether patients were randomized to receive tiotropium or placebo.

Although UPLIFT ${ }^{\circledR}$ is a placebo-controlled trial, in comparison to TORCH, the placebo group is better described as the control group. At baseline, $60 \%$ of patients in UPLIFT were being treated with ICS or LABA (either alone or in combination) and evidence suggests that more patients may have been prescribed these drugs during the trial. ${ }^{43}$ Hence, many patients in the control group in UPLIFT ${ }^{\circledR}$ could have been receiving similar medication to that of the active groups in TORCH.

Another general difference that should be highlighted is the disparity in patient numbers in the treatment groups. UPLIFT ${ }^{\circledR}$ was a two-arm study with approximately 3000 patients in each treatment arm; ${ }^{43} \mathrm{TORCH}$ was a four-arm study with approximately 1500 patients in each treatment arm. ${ }^{42}$ Both trials were designed to be sufficiently powered for the primary outcome; however, the difference in patient numbers could be a general consideration when comparing some secondary and subanalyses.

Unlike UPLIFT $^{\circledR}$, the TORCH study excluded patients based on acute reversibility to short-acting bronchodilators exceeding $10 \%$ of predicted (Table 1)..$^{39,41}$ Reversibility to short-acting bronchodilators is frequently used as a means for excluding asthmatic patients from COPD studies; ${ }^{44}$ however, several studies (including data from UPLIFT ${ }^{\circledR}$ ) indicate that such practice could also exclude patients with COPD. ${ }^{45-47}$ Repeat testing of the same patients for reversibility to bronchodilators shows considerable variability in magnitude of response. This difference in exclusion, along with the less severe postbronchodilator $\mathrm{FEV}_{1}$ inclusion criterion in UPLIFT $^{\circledR}$, may have accounted for the high proportion of GOLD stage II patients in the UPLIFT ${ }^{\circledR}$ study. Additionally, acute response to short-acting $\beta_{2}$-agonist identify a subgroup of COPD patients more likely to respond to ICS with a significant increase in $\mathrm{FEV}_{1}{ }^{48}{ }^{48}$ Therefore, excluding reversible patients in TORCH may have selected a population less likely to present positive outcomes with LABA and ICS therapy.

With respect to postbronchodilator $\mathrm{FEV}_{1}$ measurements during the trials, UPLIFT $^{\circledR}$ included use of the anticholinergic, ipratropium, as well as the short-acting $\beta_{2}$-agonist (SABA), salbutamol (albuterol), that was also used in TORCH. This was to insure maximal bronchodilation and, thereby, minimize the influence of bronchomotor tone on measurement of the rate of decline in $\mathrm{FEV}_{1}$. This difference between the trials may have little relevance beyond assessment in rate of decline except in making the actual magnitude of postbronchodilator $\mathrm{FEV}_{1}$ less comparable between the trials.

Despite the differences in the primary outcome (and hence, statistical power) and study designs, both UPLIFT ${ }^{\circledR}$ and TORCH are of sufficient size and duration to provide important insights into the natural course of COPD and the effect of pharmacologic treatment.

\section{Comparison of patients}

Demographic characteristics were similar between the two study populations. In both trials, the mean age of patients was 65 years and $75 \%$ of patients were male, which is typical of the demographic of treated patients with COPD. Mean body mass index (BMI) for both studies was also similar (25 and 26 for TORCH and UPLIFT ${ }^{\circledR}$, respectively). Mean duration of COPD was approximately 10 years in the UPLIFT ${ }^{\circledR}$ 
study; however, similar statistics were not provided for the TORCH trial.

There were fewer current smokers in UPLIFT ${ }^{\circledR}$ (approximately $30 \%$ ) compared with $43 \%$ in TORCH. Entry criteria were the same with respect to $\geq 10$ pack-years and mean pack-years were similar between the two studies (around 48 pack-years). However, smoking cessation programs were offered to all patients in UPLIFT ${ }^{\circledR}$ prior to randomization and smoking status was balanced between the two groups following randomization. ${ }^{41,43}$ In contrast, patients were stratified at randomization according to smoking status in TORCH. ${ }^{39,42}$ Since smoking cessation is known to influence the rate of decline in lung function, this difference could influence the relative rate of decline observed between the two studies.

Mean prebronchodilator $\mathrm{FEV}_{1}$ was similar between the two trials (approximately 1.1 L). Mean baseline postbronchodilator $\mathrm{FEV}_{1}$ (absolute and percent predicted) was higher in UPLIFT $^{\circledR}$ (around $47 \%$ of predicted) than in TORCH (around $44 \%$ of predicted). In contrast, the mean baseline $\mathrm{FEV}_{1} /$ forced vital capacity (FVC) was lower in UPLIFT $^{\circledR}$ (around $43 \%$ of predicted) compared with TORCH (around $48 \%$ of predicted). However, these differences between the trials may in part be due to the different short-acting bronchodilator regimen used (see above), which makes comparisons difficult.

In both studies, HRQL was measured by total score on the St George's Respiratory Questionnaire (SGRQ). Baseline SGRQ score differed between the two trials by approximately 3 units, with UPLIFT ${ }^{\circledR}$ having the lower (less severe) score. While this may not be considered as clinically relevant (ie, $\geq 4$ units), it does numerically support the suggestion from the lung function data that patients in the UPLIFT ${ }^{\circledR}$ trial were skewed towards less severe compared with patients in TORCH. Indeed, $46 \%$ of patients in UPLIFT ${ }^{\circledR}$ were reported to have GOLD stage II (moderate) COPD (three patients with GOLD stage I were enrolled, recognized as a protocol violation, but data were included). ${ }^{43}$ Similar statistics were not reported in TORCH.

\section{Comparison of the TORCH and UPLIFT ${ }^{\circledR}$ decline in lung function} Rate of decline in FEV,

The data from the post-hoc analysis of TORCH suggest that all three active groups reduce the rate of decline in postbronchodilator $\mathrm{FEV}_{1}$, the only spirometric parameter reported. ${ }^{40}$ Adjusted rates of decline in $\mathrm{FEV}_{1}$ were $-42 \pm$ $3 \mathrm{~mL} /$ year for salmeterol alone and fluticasone propionate alone, $-39 \pm 3 \mathrm{~mL} /$ year for salmeterol/fluticasone combination, and $-55 \pm 3 \mathrm{~mL} /$ year for placebo (short-acting bronchodilators) (Figure 1); this corresponded to reductions in the rate of $\mathrm{FEV}_{1}$ decline versus placebo by $13 \pm$ $4 \mathrm{~mL} /$ year each $(95 \% \mathrm{CI}, 5-22, \mathrm{p}=0.003)$ for salmeterol alone and fluticasone alone, and $16 \pm 4 \mathrm{~mL} /$ year $(95 \% \mathrm{CI}$, $7-25 ; \mathrm{p}<0.001)$ for the salmeterol/fluticasone combination. No significant differences exist between the combination and individual drugs alone. Nearly $18 \%$ of patients randomized to the placebo group in TORCH withdrew before contributing an $\mathrm{FEV}_{1}$ value. The TORCH authors commented that this could have underestimated the decline in lung function in the placebo group, with those patients who withdrew having

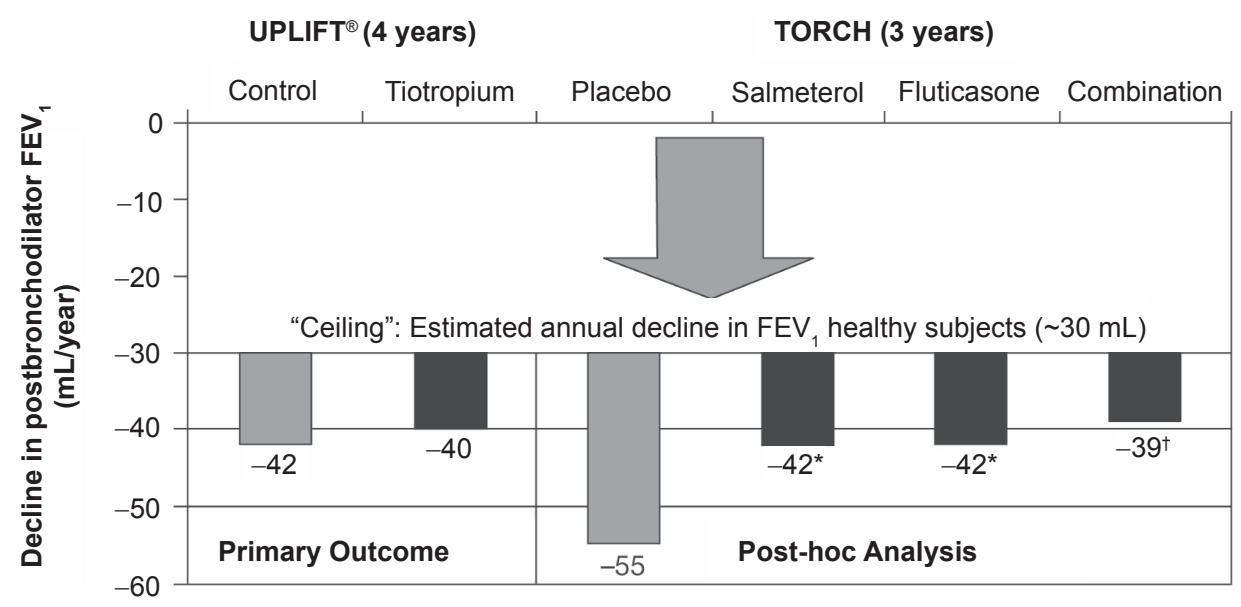

Figure I Change in rate of decline in $\mathrm{FEV}_{1}$ in UPLIFT ${ }^{\circledR}$ and TORCH, including ceiling effect (possible rate of decline in healthy individuals). Data from the individual trials have been placed on the same axes for illustrative purposes only and do not represent directly comparable data between the trials.

Notes: ${ }^{*} p=0.003$ vs placebo; ${ }^{\dagger} p<0.001$ vs placebo.

Abbreviations: $\mathrm{FEV}_{1}$, forced expiratory volume in I second. 
a steeper rate of decline. However, in an editorial, Suissa suggested that the patients who withdrew from the study could have had the lowest $\mathrm{FEV}_{1}$ values at the beginning of the study and, therefore, the "regression to the mean" could have exaggerated the rate of decline since these were the patients with the slowest decline in $\mathrm{FEV}_{1}{ }^{49}$

The data from the TORCH post-hoc analysis is valuable, but adds to the ambiguity of understanding. Inhaled Steroids in Obstructive Lung Disease in Europe (ISOLDE) study was specifically designed to investigate the effect of fluticasone priopionate on the rate of decline in $\mathrm{FEV}_{1}$ but suggested there was no additional effect above that

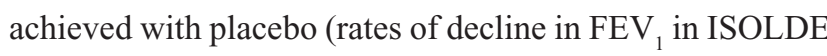
were $-50 \pm 4$ vs $-59 \pm 4 \mathrm{~mL} /$ year for the active vs shortacting bronchodilators [placebo] groups; $\mathrm{p}=0.16) .{ }^{31}$ The effect of ICS on the rate of decline in $\mathrm{FEV}_{1}$ were reported from two meta-analyses of randomized placebo-controlled trials $\geq 1$ year in length. ${ }^{32,33}$ The majority of the same trials were included in both meta-analyses. Sutherland et al reported significantly lower rates of decline in $\mathrm{FEV}_{1}$ with ICS than placebo $(-7.7 \mathrm{~mL} / \text { year vs placebo; } \mathrm{p}=0.02)^{32}$ whereas Highland et al reported no significant difference $(-5 \mathrm{~mL} /$ year vs placebo; $\mathrm{p}=0.11) .{ }^{33}$ Results from a pooled analysis of seven studies (total $\mathrm{N}=3911$ ) have also suggested that ICS do not affect the rate of decline in $\mathrm{FEV}_{1}(-0.01 \%$ vs placebo from months 6-36, $\mathrm{p}=0.86) .{ }^{34}$ As rate of $\mathrm{FEV}_{1}$ decline was a tertiary endpoint in $\mathrm{TORCH}$, it is sensible to view the data from this trial as hypothesis generating only; they continue to suggest the hypothesis that $\mathrm{FEV}_{1}$ decline in COPD can be reduced by pharmacotherapy.

Additional support for this hypothesis comes from a post-hoc, retrospective analysis of two 1-year trials with tiotropium. These double-blind, placebo-controlled, randomized trials comparing tiotropium (total $\mathrm{N}=971$ ) with placebo showed promising improvement in the rate of decline of $\mathrm{FEV}_{1}$. The mean decline in trough (premedication) $\mathrm{FEV}_{1}$ was $46 \mathrm{~mL} /$ year lower between Days 8 and $344(\mathrm{p}=0.005)$ and $40 \mathrm{~mL} /$ year lower between Days 50 and $344(\mathrm{p}=0.036)$ versus short-acting bronchodilators (placebo). ${ }^{36}$ These data, along with the TORCH post-hoc data, suggest that $\mathrm{FEV}_{1}$ decline can be reduced by effective treatment with maintenance long-acting bronchodilator therapy alone.

UPLIFT $^{\circledR}$ was specifically designed to prospectively test the reduction in decline in pre- and post-bronchodilator $\mathrm{FEV}_{1}$ with tiotropium in a controlled, 4-year study. UPLIFT ${ }^{\circledR}$ showed no difference between tiotropium and the control group in terms of rate of decline in $\mathrm{FEV}_{1}$ (calculated from Day 30 until end of study) for both components of the primary outcome: differences were $2 \mathrm{~mL} / \mathrm{year}$ when measured postbronchodilator $(-40 \pm 1$ vs $-42 \pm 1 \mathrm{~mL} /$ year; $\mathrm{p}=0.21$; Figure 1$)$ and $0 \mathrm{~mL} /$ year when measured prebronchodilator $(-30 \pm 1 \mathrm{~mL} /$ year for each group; $\mathrm{p}=0.95) .{ }^{43}$ Similar data were also reported for tiotropium versus control for the secondary endpoints of pre- and postbronchodilator rates of decline in FVC $(-43 \pm 3$ vs $-39 \pm 3, p=0.30$ and $-61 \pm 3$ vs $-61 \pm 3, p=0.84$, respectively) and slow vital capacity (SVC) $(-47 \pm 3$ vs $-41 \pm 3 \mathrm{~mL} /$ year, $\mathrm{p}=0.11$ and $-66 \pm 3$ vs $-65 \pm 3, p=0.79$, respectively). In isolation, and since this was a specifically designed trial, these data would seemingly suggest that pharmacotherapy cannot reduce the rate of decline in lung function; however, this may not be the case.

Considering the UPLIFT ${ }^{\circledR}$ and TORCH data together, and in the context of other studies, may indicate an important insight into the decline in $\mathrm{FEV}_{1}$. The rate of decline observed in the control arm of UPLIFT ${ }^{\circledR}(-42 \mathrm{~mL} /$ year $)$ is similar to that for the active monotherapy groups in TORCH $(-42 \mathrm{~mL} /$ year $)$. The active group in UPLIFT $^{\circledR}$ produced a similar rate of decline to the TORCH salmeterol/fluticasone combination group ( $-40 \mathrm{vs}-39 \mathrm{~mL} /$ year). As the TORCH investigators indicated, the TORCH placebo group was similar to the placebo groups reported in previous trials. ${ }^{19,20,27,28,30,31,34}$ However, the UPLIFT ${ }^{\circledR}$ control group included patients treated with LABA and ICS (72\%, 74\%, and 46\% received LABA, ICS, or LABA/ICS combination, respectively), therefore, could be considered a more "active" control group than the TORCH placebo. It is possible that tiotropium was unable to further reduce this decline due to a ceiling effect (ie, medications can only reduce the rate of decline to a certain amount since there is a basal rate of decline in $\mathrm{FEV}_{1}$ in normal individuals) (Figure 1).

The UPLIFT ${ }^{\circledR}$ authors suggest some preliminary evidence to support the above hypothesis of a ceiling effect. Subgroup analysis of the 1554 patients not receiving ICS or LABA at baseline showed a significantly lower postbronchodilator rate of decline in $\mathrm{FEV}_{1}$ for tiotropium versus control (40 \pm 3 vs $47 \pm 3 \mathrm{~mL} /$ year; $\mathrm{p}=0.046) .{ }^{43}$ However, this needs further investigation, since interpretation is currently difficult. As such, the greater effect size seen in TORCH compared with UPLIFT $^{\circledR}$ may be driven by the less active treatment received by the placebo group in the TORCH study versus the control group in the UPLIFT ${ }^{\circledR}$ study.

In previous studies, the rate of decline in $\mathrm{FEV}_{1}$ seen in both active and placebo groups has been higher than those seen in UPLIFT ${ }^{\circledR}$ and TORCH. For example, in the European Respiratory Society Study on Chronic Obstructive 
Pulmonary Disease (EUROSCOP) ${ }^{28}$ Bronchitis Randomized on NAC Cost-Utility Study (BRONCUS), ${ }^{27}$ and ISOLDE study, ${ }^{31}$ declines in postbronchodilator $\mathrm{FEV}_{1}$ were between 44 and $57 \mathrm{~mL} /$ year and 47 and $69 \mathrm{~mL} /$ year in the active and placebo (short-acting bronchodilators) groups, respectively. Therefore, results from TORCH and UPLIFT ${ }^{\circledR}$ suggest that all treatments, including maintenance therapy with longacting bronchodilators, can reduce the rate of decline in $\mathrm{FEV}_{1}$, with the impact on this decline being dependent on the type of agent or combination of agents received.

Subgroup analyses of UPLIFT ${ }^{\circledR}$ and TORCH also provide us with some insight into patient characteristics that may affect the rate of $\mathrm{FEV}_{1}$ decline (Table 2). There are some consistencies in the results seen in the studies. For instance, seemingly contrary to previous models of decline in lung function in COPD, ${ }^{17}$ decline is more rapid in younger patients (aged $<55$ years) than older patients. BMI was associated with the rate of $\mathrm{FEV}_{1}$ decline, with a higher BMI seemingly being beneficial in both trials. Low BMI and fat-free mass are known independent predictors of disease severity and mortality; ${ }^{50,51}$ however, this association with rate of $\mathrm{FEV}_{1}$ decline is a novel finding. Although the rate of $\mathrm{FEV}_{1}$ decline appears to be more rapid in men than women, percentage changes in rate of decline in $\mathrm{FEV}_{1}$ were similar between the sexes, suggesting that this may be associated with airway size rather than a true difference in rate of disease progression. Geographical region was also associated with the rate of decline; however, with the exception of a lower rate of decline in Asia, this was not consistent between the studies and, therefore, could also be an artefact of airway size. In $\mathrm{UPLIFT}^{\circledR}$, the rate of $\mathrm{FEV}_{1}$ decline was more rapid in earlier stages of COPD (GOLD stage II vs stages III and IV); importantly, there is some suggestion that tiotropium may positively affect the rate of decline in these earlier stage patients $(p=0.02)$, although further supportive evidence is required to confirm this observation.

\section{Absolute changes in FEV}

Both trials show that improvements in $\mathrm{FEV}_{1}$ are sustained over a considerable period after initiation of treatment. In UPLIFT $^{\circledR}$, lung function was significantly better with tiotropium than control at all measured time points throughout the trial (difference in mean $\mathrm{FEV}_{1}$ values ranged between 87 and $103 \mathrm{~mL}$, and 47 and $65 \mathrm{~mL}$ for pre- and postbronchodilator measurements, respectively; $p<0.001)$. In the tiotropium group, mean $\mathrm{FEV}_{1}$ values returned to baseline level after around 24 months (postbronchodilator) and 48 months (prebronchodilator), whereas mean $\mathrm{FEV}_{1}$ values in the control group returned to baseline after only around 12 and 10 months, respectively. Similar patterns for postbronchodilator $\mathrm{FEV}_{1}$ values were observed in the TORCH study, with a reported difference in mean change from baseline over the 3 -year trial period compared with placebo of $93 \mathrm{~mL}$ with the combination, $42 \mathrm{~mL}$ with salmeterol monotherapy and $47 \mathrm{~mL}$ with fluticasone monotherapy (all $\mathrm{p}<0.001$, as was the comparison between the combination and monotherapies). Mean postbronchodilator $\mathrm{FEV}_{1}$ values returned to baseline level after around 30 months in the combination group, compared with approximately 18 months in the monotherapy groups and approximately 6 months in the placebo group. Prebronchodilator mean $\mathrm{FEV}_{1}$ values were not reported. In the ISOLDE study, the mean $\mathrm{FEV}_{1}$ (postbronchodilator) was also significantly higher in the ICS group than the placebo group (by $76 \mathrm{~mL}$ and $100 \mathrm{~mL}$ at the 3- and 36-month time points, respectively; $\mathrm{p} \leq 0.001) .{ }^{31}$

An interesting phenomenon in UPLIFT $^{\circledR}$ was the improvement in postbronchodilator spirometry values. The expected "maximal bronchodilation" produced by the highdose salbutamol and ipratropium may have been expected to cause patients in the two treatment groups to be equal in terms of bronchodilation capacity postbronchodilator. However, postbronchodilator $\mathrm{FEV}_{1}$ and $\mathrm{FVC}$ values were higher with tiotropium than control at all time points. This finding is difficult to interpret given the complexity from the use of three bronchodilators (two of which were anticholinergics) and factors other than airway diameter that could affect spirometry.

Overall, evidence gained from UPLIFT ${ }^{\circledR}$, TORCH, and previous, smaller studies indicate that, while it is difficult to conclude that long-acting bronchodilators significantly reduce the rate of decline in lung function, these agents certainly improve lung function. Therefore, they may delay disease progression even if they do not affect the disease course itself. This is contrary to smoking cessation, which, provided it occurs sufficiently early in the course of COPD, can reduce the rate of decline in $\mathrm{FEV}_{1}$ but does not restore lung function that has been lost. ${ }^{17,21}$ As pharmacotherapy in COPD can improve lung function, there is an argument for administering pharmacotherapy at a similarly early stage in COPD.

\section{Comparison of exacerbation data}

Exacerbations are part of the natural course of COPD ${ }^{52}$ and are responsible for the morbidity and mortality of this disease. ${ }^{26,53-55}$ Exacerbations are associated with reduced quality of life ${ }^{56-58}$ and increased mortality. ${ }^{59}$ They are also the 
Table 2 Mean (SE) rate of decline (mL/year) in postbrochodilator FEV by subgroup

\begin{tabular}{|c|c|c|c|c|c|c|}
\hline & \multicolumn{4}{|l|}{ UPLIFT $^{\circledR}$} & \multicolumn{2}{|l|}{ TORCH $^{40}$} \\
\hline & Control & Tiotropium & Difference & $p$ value & All patients & $p$ value \\
\hline Age (years) & & & & $0.57^{a}$ & & $<0.00 \mathrm{I}^{\mathrm{b}}$ \\
\hline$<55$ & $54(4)$ & $47(3)$ & $-6(5)$ & 0.21 & $51.7(4.3)$ & \\
\hline$\geq 55,<65$ & $48(2)$ & $45(2)$ & $-3(3)$ & 0.29 & $51.3(2.6)$ & \\
\hline$\geq 65,<75$ & $35(2)$ & $36(2)$ & I (3) & 0.84 & $39.5(2.4)$ & \\
\hline$\geq 75$ & $35(4)$ & $29(4)$ & $-6(6)$ & 0.35 & 36.7 (4.7) & \\
\hline Smoking status & & & & $0.90^{\mathrm{a}}$ & & $<0.00 \mathrm{I}^{\mathrm{b}}$ \\
\hline Former & $38(2)$ & $36(2)$ & $-2(2)$ & 0.34 & $36.6(2.1)$ & \\
\hline Current & $52(3)$ & $50(2)$ & $-4(4)$ & 0.45 & $55.0(2.3)$ & \\
\hline Region $^{c}$ & & & & $0.8 I^{a}$ & & $<0.00 \mathrm{I}^{\mathrm{b}}$ \\
\hline Asia $^{c}$ & $31(6)$ & $26(5)$ & $-5(8)$ & 0.54 & $30.7(4.2)$ & \\
\hline Eastern Europe & $43(3)$ & $45(3)$ & $2(4)$ & 0.61 & $38.2(3.3)$ & \\
\hline Latin America & $44(5)$ & $42(5)$ & $-2(7)$ & 0.82 & $\mathrm{n} / \mathrm{a}$ & \\
\hline US & $39(3)$ & $35(3)$ & $-4(4)$ & 0.34 & $49.4(3.4)$ & \\
\hline Western Europe & $45(2)$ & $4 \mid(2)$ & $-4(3)$ & 0.22 & $50.9(2.8)$ & \\
\hline Other & $\mathrm{n} / \mathrm{a}$ & $\mathrm{n} / \mathrm{a}$ & $\mathrm{n} / \mathrm{a}$ & $\mathrm{n} / \mathrm{a}$ & $48.4(4.2)$ & \\
\hline Gender & & & & $0.63^{a}$ & & $<0.027^{b}$ \\
\hline Male & $43(1)$ & $4 I(I)$ & $-2(2)$ & 0.38 & $46.6(1.8)$ & \\
\hline Female & $39(3)$ & $35(3)$ & $-4(4)$ & 0.29 & $38.5(3.2)$ & \\
\hline GOLD Stage & & & & $0.08^{a}$ & & $n / p$ \\
\hline $\mathrm{I} / \mathrm{II}$ & $49(2)$ & $43(2)$ & $-6(3)$ & 0.02 & $n / p$ & \\
\hline III & $38(2)$ & $39(2)$ & $0(3)$ & 0.87 & $n / p$ & \\
\hline IV & $23(5)$ & $32(5)$ & $9(7)$ & 0.24 & $\mathrm{n} / \mathrm{p}$ & \\
\hline BMI $^{d}$ & & & & $0.77^{a}$ & & $<0.00 \mathrm{I}^{\mathrm{b}}$ \\
\hline$<20$ & $55(4)$ & $53(4)$ & $-I(6)$ & 0.85 & $5 I . I(4.4)$ & \\
\hline$\geq 20,<25$ & $49(2)$ & $44(2)$ & $-5(3)$ & 0.12 & $50.2(2.5)$ & \\
\hline$\geq 25,<30^{d}$ & $37(2)$ & $36(2)$ & $-2(3)$ & 0.59 & $42.1(2.9)$ & \\
\hline$\geq 30^{\mathrm{d}}$ & $34(3)$ & $34(3)$ & $0(4)$ & 0.98 & $35.1(3.2)$ & \\
\hline \multicolumn{7}{|c|}{ Concomitant medication } \\
\hline LABA & & & & $0.57^{\mathrm{a}}$ & & $n / p$ \\
\hline Yes & $44(2)$ & $40(2)$ & $-4(3)$ & 0.22 & $n / p$ & \\
\hline No & $4 \mathrm{I}(2)$ & $39(2)$ & $-2(2)$ & 0.54 & $\mathrm{n} / \mathrm{p}$ & \\
\hline ICS & & & & $0.68^{\mathrm{a}}$ & & $n / p$ \\
\hline Yes & $45(2)$ & $42(2)$ & $-3(3)$ & 0.27 & $n / p$ & \\
\hline No & $40(2)$ & $38(2)$ & $-2(2)$ & 0.47 & $\mathrm{n} / \mathrm{p}$ & \\
\hline$L A B A+I C S$ & & & & $0.7 I^{\mathrm{a}}$ & & $n / p$ \\
\hline Yes & $43(2)$ & $42(2)$ & $-2(3)$ & 0.52 & $n / p$ & \\
\hline No & $4 \mid(2)$ & $38(2)$ & $-3(3)$ & 0.26 & $n / p$ & \\
\hline Anticholinergics & & & & $0.69^{a}$ & & $n / p$ \\
\hline Yes & $42(2)$ & $39(2)$ & $-3(3)$ & 0.22 & $n / p$ & \\
\hline No & $42(2)$ & $41(2)$ & $-2(3)$ & 0.60 & $n / p$ & \\
\hline
\end{tabular}

aSubgroup by treatment interaction; 'bffect of covariate on slopes of all patients pooled regardless of study drug group; ' $\mathrm{G}$ Geographical descriptions of different trials. Pacific countries were combined with Asia in TORCH; ${ }^{\mathrm{B} B M I}$, weight $(\mathrm{kg}) /[\text { height }(\mathrm{m})]^{2}$. 29 was the cut-off for TORCH.

Abbreviations: n/a, not applicable; n/p, not published; GOLD, Global Initiative for Chronic Obstructive Lung Disease; BMI, body mass index; ICS, inhaled corticosteroids; LABA, long-acting $\beta_{2}$-agonists. 
main driver of costs in COPD.${ }^{60}$ Unsurprisingly, therefore, reducing exacerbations is a key goal of COPD treatment. ${ }^{44}$

There is inconsistency in how exacerbations are defined and analyzed, which makes it difficult to compare data on exacerbations between trials. ${ }^{61}$ In UPLIFT ${ }^{\circledR}$, an exacerbation was defined as "an increase or new onset of more than one of the following respiratory symptoms (cough, sputum, sputum purulence, wheezing, dyspnea) with a duration of 3 or more days requiring treatment with an antibiotic and/or systemic (oral, intramuscular or intravenous) steroid". ${ }^{41}$ Exacerbations were categorized as mild (treated at home without seeing a healthcare provider), moderate (visit with healthcare provider, at home or as outpatient), or severe (requiring hospitalization for $>24$ hours). In TORCH, exacerbations were defined as symptomatic deterioration requiring treatment with systemic corticosteroids and/or antibiotics (moderate exacerbation) or hospitalization (severe exacerbation). ${ }^{39,42}$
In UPLIFT $^{\circledR}$, compared with control, tiotropium significantly delayed time-to-first exacerbation (16.7 vs 12.5 months) and time-to-first hospitalization for exacerbations (lower risk of hospitalization; HR, 0.86 [95\% CI, 0.78-0.95]; $\mathrm{p}=0.002$ ) (Table 3). ${ }^{43}$ Exacerbations requiring hospitalization were infrequent ( 0.15 vs 0.16 per patient-year), which may explain why any difference between tiotropium and placebo groups was not statistically significant $(\mathrm{p}=0.34)$. Tiotropium also reduced the mean number of exacerbations by $14 \%$ (rate per patient-year, 0.73 vs 0.85 ; HR, 0.86 [95\% CI, 0.81-0.91]; $\mathrm{p}<0.001$ ), and reduced the number of days with exacerbations (13.64 vs 12.11; HR, 0.89 [95\% CI, 0.83-0.95]; $\mathrm{p}=0.001)$ compared with control. These results were consistent with those from other shorter duration studies in which tiotropium has been shown to reduce the number of exacerbations by $20 \%$ to $50 \%,{ }^{62-66}$ number of exacerbation days by $31 \%$ to $50 \%,{ }^{63,65,66}$ number of

Table 3 Exacerbations

\begin{tabular}{|c|c|c|c|c|c|c|}
\hline & \multicolumn{2}{|c|}{ UPLIFT $^{\circledR}$ (4 years) } & \multicolumn{4}{|c|}{ TORCH (3 years) } \\
\hline & Control & Tiotropium & Placebo $^{\mathbf{a}}$ & Salmeterol & Fluticasone & Combination \\
\hline \multicolumn{7}{|l|}{ Time to first exacerbation } \\
\hline Median $(95 \% \mathrm{Cl})$, months & $\begin{array}{l}12.5 \\
(11.5-13.8)\end{array}$ & $\begin{array}{l}16.7 \\
(14.9-17.9)\end{array}$ & \multicolumn{4}{|c|}{ Not published } \\
\hline Hazard ratio $(95 \% \mathrm{Cl})$, vs control & - & $\begin{array}{l}0.86 \\
(0.8 I-0.9 I)\end{array}$ & & & & \\
\hline $\begin{array}{l}\text { Hazard ratio }(95 \% \mathrm{Cl}) \text { for first } \\
\text { hospitalization for exacerbation, } \\
\text { vs control }\end{array}$ & - & $\begin{array}{l}0.86 \\
(0.78-0.95)\end{array}$ & & & & \\
\hline \multicolumn{7}{|l|}{ Exacerbation rate } \\
\hline Exacerbations/patient-year ${ }^{\mathrm{b}}$ & $0.85(0.02)$ & $0.73(0.02)$ & 1.13 & 0.97 & 0.93 & 0.85 \\
\hline Rate ratio $(95 \% \mathrm{Cl})$, vs control & - & $\begin{array}{l}0.86 \\
(0.8 I-0.9 I)\end{array}$ & - & $\begin{array}{l}0.85 \\
(0.78-0.93)\end{array}$ & $\begin{array}{l}0.82 \\
(0.76-0.89)\end{array}$ & $\begin{array}{l}0.75 \\
(0.69-0.8 I)\end{array}$ \\
\hline $\begin{array}{l}\text { Exacerbations requiring } \\
\text { hospitalization/patient-year }\end{array}$ & $0.16(0.01)$ & $0.15(0.01)$ & 0.19 & 0.16 & 0.17 & 0.16 \\
\hline Rate ratio $(95 \% \mathrm{Cl})$, vs control & - & $\begin{array}{l}0.94^{\mathrm{c}} \\
(0.82-1.07)\end{array}$ & - & $\begin{array}{l}0.82 \\
(0.69-0.96)\end{array}$ & $\begin{array}{l}0.88^{c} \\
(0.74-1.03)\end{array}$ & $\begin{array}{l}0.83 \\
(0.7 \mathrm{I}-0.98)\end{array}$ \\
\hline $\begin{array}{l}\text { Exacerbations requiring systemic } \\
\text { corticosteroids/patient-year }\end{array}$ & \multirow{2}{*}{\multicolumn{2}{|c|}{ Not published }} & 0.80 & 0.64 & 0.52 & 0.46 \\
\hline Rate ratio $(95 \% \mathrm{Cl})$, vs control & & & - & $\begin{array}{l}0.80 \\
(0.72-0.90)\end{array}$ & $\begin{array}{l}0.65 \\
(0.58-0.73)\end{array}$ & $\begin{array}{l}0.57 \\
(0.51-0.64)\end{array}$ \\
\hline Exacerbation days/patient-year ${ }^{b}$ & I3.64 (0.35) & $12.11(0.32)$ & \multicolumn{4}{|c|}{ Not published } \\
\hline Rate ratio $(95 \% \mathrm{Cl})$, vs control & - & $\begin{array}{l}0.89 \\
(0.83-0.95)\end{array}$ & & & & \\
\hline Hospitalization days/patient-year ${ }^{\mathrm{b}}$ & $3.13(0.17)$ & $3.17(0.17)$ & \multicolumn{4}{|c|}{ Not published } \\
\hline Rate ratio $(95 \% \mathrm{Cl})$, vs control & - & $\begin{array}{l}1.0 I^{\mathrm{c}} \\
(0.87-1.18)\end{array}$ & & & & \\
\hline
\end{tabular}

aShort-acting bronchodilators were permitted throughout the study; ${ }^{b}$ Mean (SE); cNot statistically significant. Abbreviation: $\mathrm{Cl}$, confidence interval. 
hospitalizations due to exacerbations by $20 \%$ to $30 \%{ }^{67}$ and time-to-first exacerbation. ${ }^{62,63,65}$ Compared with short-acting bronchodilators, associated healthcare resource utlilization was also consistently reduced with tiotropium in these earlier studies. ${ }^{63,65,67}$

Rates of moderate or severe exacerbations per patient-year were reduced in all active groups in the TORCH study $(0.85$, $0.93,0.97$, and 1.13 for combination, fluticasone only, salmeterol only, and placebo groups, respectively; $\mathrm{p}<0.001$ vs placebo); significantly lower rates were also seen with the combination group vs salmeterol $(\mathrm{p}=0.002)$ and fluticasone $(\mathrm{p}=0.02)$ monotherapy groups (Table 3$).{ }^{42}$ Both the combination and salmeterol groups reduced, by the same magnitude, the rate of exacerbations requiring hospitalization versus placebo ( 0.16 and 0.16 vs 0.19 per patient-year; $\mathrm{p}=0.03$ and $\mathrm{p}=0.02$, respectively). ${ }^{42}$ No data on time-tofirst exacerbation, number of days with exacerbations, or number of days in hospital in TORCH were published. These data confirm those from a previous 1-year study in which salmeterol/fluticasone combination and the single agents have reduced the frequency of exacerbations by $25 \%$ and $19 \%$ to $20 \%$, respectively. ${ }^{68}$

It is possible to draw some comparisons between the UPLIFT $^{\circledR}$ and TORCH findings despite the difference in counting and analyses. There were significant improvements in multiple measures of exacerbations with the active groups in both trials. In terms of rates of exacerbations per patientyear, these were slightly lower with tiotropium compared with the active treatment groups in TORCH $(0.73$ vs 0.85-0.97). Similar to the results for lung function decline, the exacerbation rate ( 0.85 per patient-year) in the placebo group in UPLIFT ${ }^{\circledR}$ was closer to the rates seen in the active treatment groups in TORCH than the TORCH placebo group (exacerbation rate of 1.13 per patient-year). Again, the fact that the UPLIFT ${ }^{\circledR}$ placebo group included patients treated with LABA and ICS, and the postulated "ceiling effect" described above, may explain why there was a relatively low rate of exacerbation in this group compared with the TORCH placebo group and, therefore, why the extent of the improvement beyond this (14\%) with tiotropium was lower than the $25 \%$ improvement seen in TORCH (Figure 2). This may also suggest a benefit from a triple combination of tiotropium, LABA and ICS.

Reduction in exacerbations and exacerbations leading to hospitalization is one of the mechanisms that may explain a reduction in mortality in both trials. The mechanism of the link between exacerbations and mortality could be associated with hyperinflation, which is also related to mortality. ${ }^{69}$
UPLIFT $^{\circledR}(4$ years $)$

TORCH (3 years)

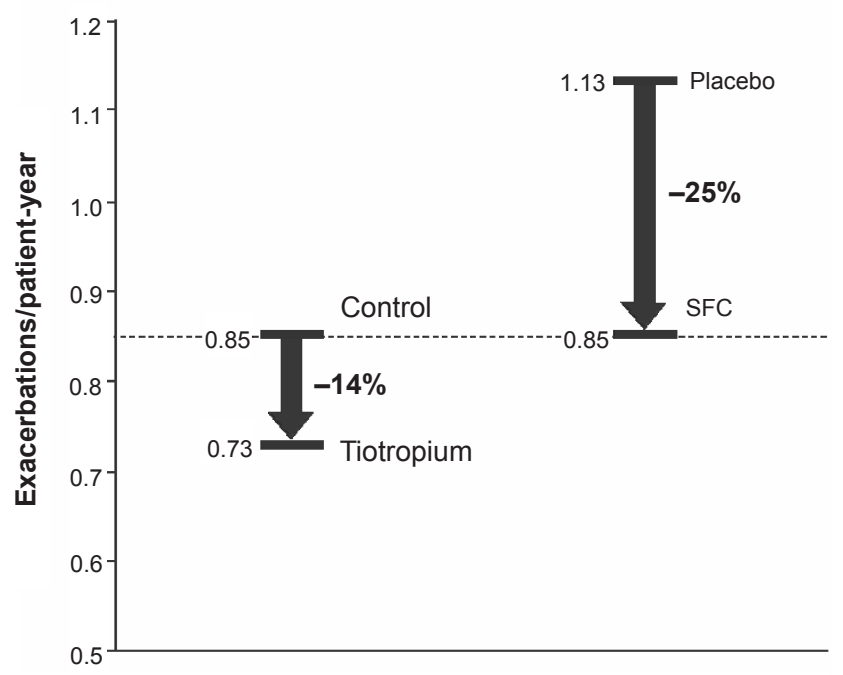

Figure 2 Change in exacerbation rates by the active treatment groups in UPLIFT ${ }^{\oplus}$ and TORCH. Data from the individual trials have been placed on the same axes for illustrative purposes only and do not represent directly comparable data between the trials.

Hyperinflation is likely to worsen during exacerbations of COPD. Tiotropium, salmeterol, and the combination of salmeterol and fluticasone are effective in reducing hyperinflation and improving exercise capacity. ${ }^{70-74}$

\section{Comparison of HRQL data}

Both trials evaluated HRQL using SGRQ. This is one of the most widely used instruments for measuring HRQL in respiratory patients, and has been used extensively in therapeutic evaluation studies.

Comparing the results of UPLIFT ${ }^{\circledR}$ and TORCH (Table 4), all treatments failed to achieve a mean clinical significance at the end of the trials, ie, a mean reduction of 4 or more units on the SGRQ total score. However, all treatments achieved statistical significance. Statistically significant differences in mean change in SGRQ total score were observed at all time points throughout the UPLIFT ${ }^{\circledR}$ trial, in favor of tiotropium. In $\mathrm{TORCH}$, time point data were not reported; instead, mean changes in SGRQ total score were averaged over 3 years, which demonstrated a statistically significant improvement in the combination therapy group compared with the placebo and monotherapy groups.

In addition, a significantly higher proportion of patients in the tiotropium group than the control group in UPLIFT ${ }^{\circledR}$ had an improvement of 4 or more units from baseline at 1 year (49\% vs $41 \%), 2$ years (48\% vs 39\%), 3 years (46\% vs 37\%), and 4 years ( $45 \%$ vs $36 \%$; p $<0.001$ for all comparisons). These data compare favorably with a previous 


\begin{tabular}{|c|c|c|c|c|c|c|}
\hline & \multicolumn{2}{|c|}{ UPLIFT $^{\circledR}$ (4 years) } & \multicolumn{4}{|c|}{ TORCH (3 years) } \\
\hline & Control & Tiotropium & Placebo & Salmeterol & Fluticasone & Combination \\
\hline$\%$ with $\geq 4$ unit change at end of trial & 36 & 45 & & Not published & & \\
\hline $\begin{array}{l}\text { Mean }(95 \% \mathrm{Cl}) \text { difference from control } \\
\text { over trial period, units }\end{array}$ & - & $\begin{array}{l}-2.7 \\
(-3.3--2.0)^{\mathrm{a}}\end{array}$ & - & $\begin{array}{l}-1.0^{\mathrm{b}} \\
(-2.0-0)\end{array}$ & $\begin{array}{l}-2.0 \\
(-2.9--1.0)\end{array}$ & $\begin{array}{l}-3.1 \\
(-4.1--2.1)\end{array}$ \\
\hline Rate of decline, units/yearc & $1.21(0.09)$ & $1.25(0.09)$ & \multicolumn{4}{|c|}{ Not published } \\
\hline$\Delta$ from control & - & $0.04(0.13)^{\mathrm{b}}$ & & & & \\
\hline
\end{tabular}

Notes: ${ }^{a} U P L I F{ }^{\oplus}$ also published the range of mean differences from placebo over the 4 -year trial as $-3.3--2.3$ ( $P<0.001$ ); ${ }^{b}$ Not statistically significant; ${ }^{\mathrm{c}}$ Mean (SE). Abbreviations: SGRQ, St. George's Respiratory Questionnaire; $\mathrm{Cl}$, confidence interval.

long-term study of tiotropium in which the percentages of patients with a clinically meaningful response after 1 year were $49 \%$ and $30 \%$ in the tiotropium and placebo groups, respectively. ${ }^{75}$ The proportion of patients in TORCH achieving a change of at least 4 units on the SGRQ total score was not reported, preventing further comparison between the two studies.

Similar to the lung function results, no between-group differences were observed in UPLIFT ${ }^{\circledR}$ in the rate of decline in SRGQ scores (Table 4). The permitted use of ICS, LABA, and their combinations as rescue medication, together with the unrestricted use of medications to treat exacerbations in UPLIFT $^{\circledR}$, may have narrowed any between-treatment improvements in HRQL. As previously stated, maintenance treatment with inhaled fluticasone alone affected the rate of deterioration in SGRQ in the ISOLDE trial. ${ }^{76}$ Rate of decline in SRGQ scores has not yet been reported from TORCH.

\section{Comparison of mortality data}

A key goal of COPD therapy is to reduce mortality. ${ }^{44}$ In UPLIFT $^{\circledR}$, mortality data have been reported for two intentto-treat 4-year "vital status" analyses for which at least 45 months follow-up was available, including patients who had discontinued, and for patients "on treatment". ${ }^{43}$ These analyses were a) from Days 1-1440 (planned 4 years of study treatment), b) the protocol-defined on-treatment period of 1470 days (1440 days planned treatment plus 30 days follow-up), and c) the first to actual last day of treatment plus 30 days follow-up. The difference in 4-year all-cause mortality between the tiotropium and placebo groups was not statistically significant for the protocol-defined 1470-day vital status analysis $(\mathrm{p}=0.09)$ (Table 5); a significant difference between groups was observed, however, according to both the 1440-day analysis and the on-treatment analysis. A possible reason for the difference between the 1470-day and the other analyses is that data were received on only $75 \%$ of patients for the former compared with, for example, $95 \%$ of patients for the 1440-day analysis. A recent meta-analysis of safety with tiotropium has addressed a composite variable of cardiovascular death, non-fatal myocardial infarction or non-fatal stroke. ${ }^{77}$ The results of this meta-analysis is discussed later in the safety and tolerability section.

In TORCH, mortality data was on an intent-to-treat basis and was analyzed from Day 1 to the end of the treatment period (3 years). Unlike UPLIFT ${ }^{\circledR}$, the follow-up period ( 15 days in TORCH; 30 days in UPLIFT ${ }^{\circledR}$ ) was not included. There was no statistically significant difference in the 3 -year all-cause mortality rate between the salmeterol/fluticasone combination group and the placebo group $(\mathrm{p}=0.052)$ (Table 5). A slightly higher mortality rate was observed in the salmeterol-only arm (13.5\%) than the combination arm (difference not significant vs combination arm [12.6\%] or placebo [15.2\%]). In the fluticasone-only arm, the mortality rate (16\%) was actually higher numerically than placebo and significantly higher than in the combination arm $(\mathrm{p}=0.007)$.

Although the UPLIFT ${ }^{\circledR}$ and TORCH studies are not directly comparable, Figure 3 provides a comparison similar to Figure 1. The results of UPLIFT ${ }^{\circledR}$ showed that a long-acting bronchodilator (tiotropium) appeared to have an impact on mortality. Consistent with this, after factorial analysis, some authors suggested that the effect on mortality observed in the combination arm in TORCH is entirely due to the long-acting bronchodilator, ie, the LABA (salmeterol). ${ }^{49,78}$ Indeed, a higher mortality rate was seen in the fluticasone-only arm compared with the combination arm and with placebo (difference vs placebo was not significant). The role of ICS in long-term treatment in COPD is still under debate. ${ }^{79,80}$

Overall, the results from UPLIFT ${ }^{\circledR}$ and TORCH suggest that both tiotropium and the salmeterol/fluticasone combination may reduce the risk of mortality. 
Table 5 Mortality

\begin{tabular}{|c|c|c|c|c|c|c|}
\hline & \multicolumn{2}{|c|}{ UPLIFT $^{\circledR}$ (4 years) } & \multicolumn{4}{|c|}{ TORCH (3 years) } \\
\hline & Control & Tiotropium & Placebo $^{a}$ & Salmeterol & Fluticasone & Combination \\
\hline \multicolumn{7}{|l|}{ Percentage of deaths (\%) } \\
\hline 4-year follow-up & 16.3 & 14.4 & \multirow{2}{*}{\multicolumn{4}{|c|}{ Not applicable }} \\
\hline Hazard ratio $(95 \% \mathrm{Cl})$, vs control & - & $\begin{array}{l}0.87 \\
(0.76-0.99)\end{array}$ & & & & \\
\hline 4-year plus 30 days follow-up & 16.5 & 14.9 & \multirow{2}{*}{\multicolumn{4}{|c|}{ Not applicable }} \\
\hline Hazard ratio $(95 \% \mathrm{Cl})$, vs control & - & $\begin{array}{l}0.89^{b} \\
(0.79-1.02)\end{array}$ & & & & \\
\hline On treatment plus 30 days follow-up & 13.7 & 12.8 & \multirow{2}{*}{\multicolumn{4}{|c|}{ Not applicable }} \\
\hline Hazard ratio $(95 \% \mathrm{Cl})$, vs control & - & $\begin{array}{l}0.84 \\
(0.73-0.97)\end{array}$ & & & & \\
\hline 3-year follow up & \multirow{2}{*}{\multicolumn{2}{|c|}{ Not applicable }} & 15.2 & 13.5 & 16.0 & 12.6 \\
\hline Hazard ratio $(95 \% \mathrm{Cl})$, vs placebo & & & - & $\begin{array}{l}0.879^{\mathrm{b}} \\
(0.729-1.06 \mathrm{I})\end{array}$ & $\begin{array}{l}1.060^{\mathrm{b}} \\
(0.886-1.268)\end{array}$ & $\begin{array}{l}0.825^{b, c} \\
(0.68 \mathrm{I}-1.002)\end{array}$ \\
\hline
\end{tabular}

aShort-acting bronchodilators were permitted throughout the study; ${ }^{b}$ Not statistically significant; ${ }^{c}$ Adjusted for interim analyses.

Abbreviations: $\mathrm{Cl}$, confidence interval.

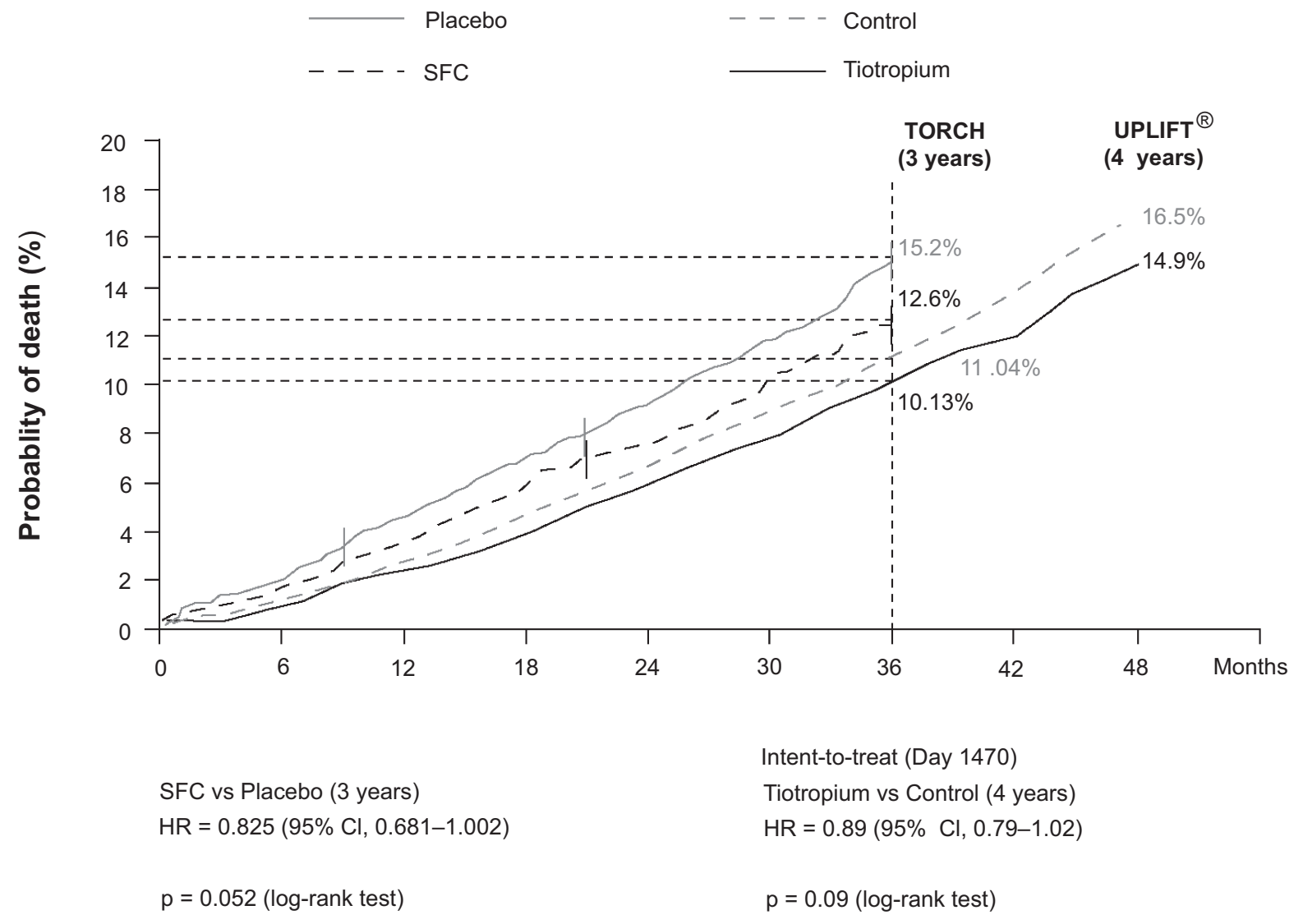

Figure 3 Comparison of selected mortality data presented in the TORCH and UPLIFT ${ }^{\circledR}$ primary publications. ${ }^{40,43}$ Data from the individual trials have been placed on the same axes for illustrative purposes only and do not represent directly comparable data between the trials.

Abbreviations: $\mathrm{Cl}$, confidence interval; HR, hazard ratio; SFC, salmeterol and fluticasone in combination. 
Table 6 The most frequently occurring adverse events categorized by ranges of incidence rate per year

\begin{tabular}{|c|c|c|c|c|c|c|}
\hline & \multicolumn{2}{|c|}{ UPLIFT $^{\circledR}$ (4 years) } & \multicolumn{4}{|c|}{ TORCH (3 years) $)^{40}$} \\
\hline & Control & Tiotropium & Placebo & Salmeterol & Fluticasone & Combination \\
\hline \multicolumn{7}{|c|}{$\begin{array}{l}\text { Incidence rate } \\
\text { per year, range } \\
\text { (actual) }\end{array}$} \\
\hline \multirow[t]{3}{*}{$\geq 0.10$} & COPD ex $(0.46)$ & COPD ex $(0.38)$ & COPD ex (0.92) & COPD ex $(0.76)$ & COPD ex $(0.78)$ & COPD ex (0.67) \\
\hline & & & $\begin{array}{l}\text { Upper RTI } \\
(0.10)\end{array}$ & & $\begin{array}{l}\text { Nasopharyngitis } \\
(0.10)\end{array}$ & Upper RTI (0.1 I) \\
\hline & & & & & & $\begin{array}{l}\text { Nasopharyngitis } \\
(0.10)\end{array}$ \\
\hline \multirow[t]{2}{*}{$0.08-0.09$} & - & - & $\begin{array}{l}\text { Nasopharyngitis } \\
(0.09)\end{array}$ & $\begin{array}{l}\text { Nasopharyngitis } \\
(0.09)\end{array}$ & Upper RTI (0.09) & $\begin{array}{l}\text { Nasopharyngitis } \\
(0.09)\end{array}$ \\
\hline & & & Headache $(0.08)$ & Upper RTI (0.08) & & \\
\hline \multirow[t]{2}{*}{$0.06-0.07$} & - & - & - & Headache $(0.06)$ & Pneumonia (0.07) & Pneumonia $(0.07)$ \\
\hline & & & & & Headache $(0.06)$ & \\
\hline \multirow[t]{4}{*}{$0.04-0.05$} & Dyspnea (0.05) & Pneumonia $(0.05)$ & Bronchitis $(0.05)$ & Bronchitis $(0.05)$ & Bronchitis $(0.05)$ & Bronchitis $(0.05)$ \\
\hline & Pneumonia $(0.05)$ & $\begin{array}{l}\text { Nasopharyngitis } \\
(0.04)\end{array}$ & $\begin{array}{l}\text { Pneumonia } \\
(0.04)\end{array}$ & $\begin{array}{l}\text { Pneumonia } \\
(0.04)\end{array}$ & Back pain (0.04) & Headache $(0.05)$ \\
\hline & $\begin{array}{l}\text { Nasopharyngitis } \\
(0.04)\end{array}$ & Dyspnea (0.04) & Back pain (0.04) & Back pain (0.04) & Sinusitis $(0.04)$ & Back pain (0.04) \\
\hline & Upper RTI (0.04) & & & & Cough $(0.04)$ & Sinusitis $(0.04)$ \\
\hline
\end{tabular}

Abbreviations: COPD ex, chronic obstructive pulmonary disease exacerbations; RTI, respiratory tract infection.

\section{Comparison of safety and tolerability data} The proportions of patients experiencing adverse events (AEs) were similar between UPLIFT ${ }^{\circledR}$ and TORCH (ranges across groups and trials were $89 \%$ to $93 \%, 40 \%$ to $52 \%$, and $18 \%$ to $25 \%$ for AEs, serious AEs [SAEs], and events leading to withdrawal, respectively). ${ }^{42,43}$ Side effects were generally those expected from the class of drugs used. In UPLIFT ${ }^{\circledR}$, tiotropium reduced the rate of cardiac (including congestive heart failure and myocardial infarction) and lower respiratory (including respiratory failure and dyspnea) SAEs compared with control $(p<0.05)$; there was no significant difference in the incidence of stroke between tiotropium and control. This finding contrasts with the suggestion from a recent meta-analysis that anticholinergics are associated with an increase in risk of cardiovascular events, ${ }^{77}$ though the results of UPLIFT ${ }^{\circledR}$ are consistent with a pooled analysis of patient-level data from 19 other trials with tiotropium. ${ }^{81}$ The most frequently occurring $\mathrm{AE}$ in all groups of both trials was COPD exacerbations (Table 6). Fluticasonecontaining treatment was associated with an increased probability of having pneumonia in TORCH. Incidences of pneumonia were $19.6 \%, 18.3 \%, 13.3 \%$, and $12.3 \%$ in the combination, fluticasone-only, salmeterol-only, and placebo arms, respectively, with significant differences between the combination and fluticasone-only arms versus placebo $(p<0.001)$ and combination versus salmeterol-only arms $(\mathrm{p}<0.001)$. There were no significant ocular or bone-related safety signals observed with active TORCH treatments. In UPLIFT $^{\circledR}$, dry mouth and constipation were observed, two side effects that are consistent with the known safety profile for tiotropium.

Overall, the results from UPLIFT ${ }^{\circledR}$ confirm the favorable safety profile with tiotropium. ${ }^{81}$ No strong safety signals were seen with salmeterol monotherapy in TORCH; the increased risk of pneumonia with fluticasone-containing regimens mirrors previous studies. ${ }^{82,83}$

\section{Conclusions}

Although neither UPLIFT ${ }^{\circledR}$ nor TORCH reached their primary endpoints, these trials have revealed the impact of long-term bronchodilators in the treatment of COPD. Long-acting bronchodilators in the form of tiotropium and salmeterol (in combination with fluticasone propionate) can actually improve lung function and may delay progression of COPD, thus positively affecting disease prognosis. Mortality may also be reduced and HRQL improved. Despite international and national guidelines recommending longacting bronchodilators for COPD, these agents are currently 
under-prescribed. UPLIFT ${ }^{\circledR}$ and TORCH results support an urgent change in prescribing practices.

\section{Acknowledgments and disclosures}

The authors are grateful for the editorial support from PAREXEL MMS in assisting in the drafting of this article. PAREXEL MMS was funded jointly by Boehringer Ingelheim and Pfizer. The authors are exclusively responsible for direction with respect to the text.

\section{References}

1. Buist AS, McBurnie MA, Vollmer WM, Gillespie S, Burney P, Mannino DM, et al. International variation in the prevalence of COPD (the BOLD Study): a population-based prevalence study. Lancet. 2007;370:741-750.

2. Halbert RJ, Natoli JL, Gano A, Badamgarav E, Buist AS, Mannino DM. Global burden of COPD: systematic review and meta-analysis. Eur Respir J. 2006;28:523-532.

3. Pena VS, Miravitlles M, Gabriel R, Jimenez-Ruiz CA, Villasante C, Masa JF, et al. Geographic variations in prevalence and underdiagnosis of COPD: results of the IBERPOC multicentre epidemiological study. Chest. 2000;118:981-989.

4. Lopez AD, Shibuya K, Rao C, Mathers CD, Hansell AL, Held LS, et al. Chronic obstructive pulmonary disease: current burden and future projections. Eur Respir J. 2006;27:397-412.

5. Celli BR, MacNee W, and committee members. Standards for the diagnosis and treatment of patients with COPD: a summary of the ATS/ERS position paper. Eur Respir J. 2004;23:932-946.

6. Jemal A, Ward E, Hao Y, Thun M. Trends in the leading causes of death in the United States, 1970-2002. JAMA. 2005;294:1255-1259.

7. World Health Organization. Chronic obstructive pulmonary disease (COPD) fact sheet No. 315;2008.

8. Miravitlles M, Murio C, Guerrero T, Gisbert R. Costs of chronic bronchitis and COPD: a 1-year follow-up study. Chest. 2003;123: 784-791

9. Serra-Batlles J, Plaza V, Morejon E, Comella A, Brugues J. Costs of asthma according to the degree of severity. Eur Respir J. 1998;12:1322-1326.

10. Pauwels RA, Rabe KF. Burden and clinical features of chronic obstructive pulmonary disease (COPD). Lancet. 2004;364:613-620.

11. Cooper CB. The connection between chronic obstructive pulmonary disease symptoms and hyperinflation and its impact on exercise and function. Am J Med. 2006;119:21-31.

12. Global Initiative for Chronic Obstructive Lung Disease. Global strategy for the diagnosis, management and prevention of chronic obstructive pulmonary disease. 2008 Update. www. goldcopd. org. 2-11-2008.

13. Traver GA, Cline MG, Burrows B. Predictors of mortality in chronic obstructive pulmonary disease. A 15-year follow-up study. Am Rev Respir Dis. 1979;119:895-902.

14. Schunemann HJ, Dorn J, Grant BJ, Winkelstein W Jr, Trevisan M. Pulmonary function is a long-term predictor of mortality in the general population: 29-year follow-up of the Buffalo Health Study. Chest. 2000;118:656-664.

15. Young RP, Hopkins R, Eaton TE. Forced expiratory volume in one second: not just a lung function test but a marker of premature death from all causes. Eur Respir J. 2007;30:616-622.

16. Mannino DM, Davis KJ. Lung function decline and outcomes in an elderly population. Thorax. 2006;61:472-477.

17. Fletcher C, Peto R. The natural history of chronic airflow obstruction. BMJ. 1977;1:1645-1648.

18. Anthonisen NR, Connett JE, Kiley JP, Altose MD, Bailey WC, Buist AS, et al. Effects of smoking intervention and the use of an inhaled anti-

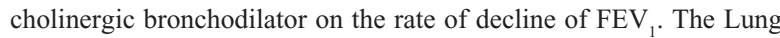
Health Study. JAMA. 1994;272:1497-1505.
19. Burchfiel CM, Marcus EB, Curb JD, MacLean CJ, Vollmer WM, Johnson LR, et al. Effects of smoking and smoking cessation on longitudinal decline in pulmonary function. Am J Respir Crit Care Med. 1995;151:1778-1785.

20. Scanlon PD, Connett JE, Waller LA, Altose MD, Bailey WC, Buist AS, et al. Smoking cessation and lung function in mild-to-moderate chronic obstructive pulmonary disease. The Lung Health Study. Am J Respir Crit Care Med. 2000;161:381-390.

21. Anthonisen NR, Connett JE, Murray RP. Smoking and lung function of Lung Health Study participants after 11 years. Am J Respir Crit Care Med. 2002;166:675-679.

22. Cazzola M, MacNee W, Martinez FJ, Rabe KF, Franciosi LG, Barnes PJ, et al. Outcomes for COPD pharmacological trials: from lung function to biomarkers. Eur Respir J. 2008;31:416-469.

23. Celli BR, Cote CG, Lareau SC, Meek PM. Predictors of Survival in COPD:

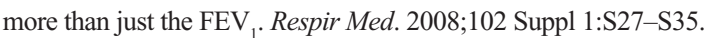

24. Cooper CB, Dransfield M. Primary care of the patient with chronic obstructive pulmonary disease-part 4: understanding the clinical manifestations of a progressive disease. Am J Med. 2008;121:S33-S45.

25. Kerstjens HA, Rijcken B, Schouten JP, Postma DS. Decline of FEV by age and smoking status: facts, figures, and fallacies. Thorax. 1997;52:820-827.

26. Donaldson GC, Seemungal TAR, Bhowmik A, Wedzicha JA. Relationship between exacerbation frequency and lung function decline in chronic obstructive pulmonary disease. Thorax. 2002;57:847-852.

27. Decramer M, Rutten-van Molken M, Dekhuijzen PN, Troosters T, van Herwaarden C, Pellegrino R, et al. Effects of N-acetylcysteine on outcomes in chronic obstructive pulmonary disease (Bronchitis Randomized on NAC Cost-Utility Study, BRONCUS): a randomised placebo-controlled trial. Lancet. 2005;365:1552-1560.

28. Pauwels RA, LofdahlCG, Laitinen LA, Schouten JP, Postma DS, Pride NB, et al. Long-term treatment with inhaled budesonide in persons with mild chronic obstructive pulmonary disease who continue smoking. $N$ Engl J Med. 1999;340:1948-1953.

29. Vestbo J, Sorensen T, Lange P, Brix A, Torre P, Viskum K. Longterm effect of inhaled budesonide in mild and moderate chronic obstructive pulmonary disease: a randomised controlled trial. Lancet. 1999;353:1819-1823.

30. The Lung Health Study Research Group. Effect of inhaled triamcinolone on the decline in pulmonary function in chronic obstructive pulmonary disease. N Engl J Med. 2000;343:1902-1909.

31. Burge PS, Calverley PMA, Jones PW, Spencer S, Anderson JA, Maslen TK. Randomised, double blind, placebo controlled study of fluticasone propionate in patients with moderate to severe chronic obstructive pulmonary disease: the ISOLDE trial. BMJ. 2000;320: 1297-1303.

32. Sutherland ER, Allmers H, Ayas NT, Venn AJ, Martin RJ. Inhaled corticosteroids reduce the progression of airflow limitation in chronic obstructive pulmonary disease: a meta-analysis. Thorax. 2003;58:937-941.

33. Highland KB, Strange C, Heffner JE. Long-term effects of inhaled corticosteroids on $\mathrm{FEV}$, in patients with chronic obstructive pulmonary disease. A meta-analysis. Ann Intern Med. 2003;138:969-973.

34. Soriano JB, Sin DD, Zhang X, Camp PG, Anderson JA, Anthonisen NR, et al. A pooled analysis of $\mathrm{FEV}_{1}$ decline in COPD patients randomized to inhaled corticosteroids or placebo. Chest. 2007;131: 682-689.

35. Garcia-Aymerich J, Lange P, Benet M, Schnohr P, Anto JM. Regular physical activity modifies smoking-related lung function decline and reduces risk of chronic obstructive pulmonary disease: a population-based cohort study. Am J Respir Crit Care Med. 2007;175: $458-463$.

36. Anzueto A, Tashkin D, Menjoge S, Kesten S. One-year analysis of longitudinal changes in spirometry in patients with COPD receiving tiotropium. Pulm Pharmacol Ther. 2005;18:75-81.

37. Soriano JB, Vestbo J, Pride NB, Kiri V, Maden C, Maier WC. Survival in COPD patients after regular use of fluticasone propionate and salmeterol in general practice. Eur Respir J. 2002;20:819-825. 
38. Sin DD, Wu L, Anderson JA, Anthonisen NR, Buist AS, Burge PS, et al. Inhaled corticosteroids and mortality in chronic obstructive pulmonary disease. Thorax. 2005;60:992-997.

39. Vestbo J. The TORCH (towards a revolution in COPD health) survival study protocol. Eur Respir J. 2004;24:206-210.

40. Celli BR, Thomas NE, Anderson JA, Ferguson GT, Jenkins CR, Jones PW, et al. Effect of pharmacotherapy on rate of decline of lung function in chronic obstructive pulmonary disease: results from the TORCH study. Am J Respir Crit. Care Med. 2008;178:332-338.

41. Decramer M, Celli B, Tashkin DP, Pauwels RA, Burkhart D, Cassino C, et al. Clinical trial design considerations in assessing long-term functional impacts of tiotropium in COPD: the UPLIFT trial. COPD. 2004;1: 303-312.

42. Calverley PMA, Anderson JA, Celli B, Ferguson GT, Jenkins C, Jones PW, et al. Salmeterol and fluticasone propionate and survival in chronic obstructive pulmonary disease. N Engl J Med. 2007;356: 775-789.

43. Tashkin DP, Celli B, Senn S, Burkhart D, Kesten S, Menjoge S, et al. A 4-year trial of tiotropium in chronic obstructive pulmonary disease. N Engl J Med. 2008;359:1543-1554.

44. Rabe KF, Hurd S, Anzueto A, Barnes PJ, Buist SA, Calverley P, et al. Global strategy for the diagnosis, management, and prevention of chronic obstructive pulmonary disease: GOLD executive summary. Am J Respir Crit Care Med. 2007;176:532-555.

45. Anthonisen NR. Bronchodilator response in chronic obstructive pulmonary disease. Am Rev Respir Dis. 1986;133:814-819.

46. Dorinsky PM, Reisner C, Ferguson GT, Menjoge SS, Serby CW, Witek TJ Jr. The combination of ipratropium and albuterol optimizes pulmonary function reversibility testing in patients with COPD. Chest. 1999;115:966-971.

47. Tashkin DP, Celli B, Decramer M, Liu D, Burkhart D, Cassino C, et al. Bronchodilator responsiveness in patients with COPD. Eur Respir J. 2008;31:742-750.

48. Bleecker ER, Emmett A, Crater G, Knobil K, Kalberg C. Lung function and symptom improvement with fluticasone propionate/salmeterol and ipratropium bromide/albuterol in COPD: response by betaagonist reversibility. Pulm Pharmacol Ther. 2008;21:682-688.

49. Suissa $\mathrm{S}$. Medications to modify lung function decline in chronic obstructive pulmonary disease: some hopeful signs. Am J Respir Crit. Care Med. 2008;178:322-323.

50. Bolton CE, Ionescu AA, Shiels KM, Pettit RJ, Edwards PH, Stone MD, et al. Associated loss of fat-free mass and bone mineral density in chronic obstructive pulmonary disease. Am J Respir Crit Care Med. 2004;170:1286-1293.

51. Schols AMWJ, Slangen J, Volovics L, Wouters EFM. Weight loss is a reversible factor in the prognosis of chronic obstructive pulmonary disease. Am J Respir Crit Care Med. 1998;157:1791-1797.

52. Anzueto A, Miravitlles M. Modifying the clinical course of COPD. Hot Topics in Respiratory Medicine. 2008;7:7-19.

53. Crooks SW, Bayley DL, Hill SL, Stockley RA. Bronchial inflammation in acute bacterial exacerbations of chronic bronchitis: the role of leukotriene B4. Eur Respir J. 2000;15:274-280.

54. Stanescu D, Sanna A, Veriter C, Kostianev S, Calcagni PG, Fabbri LM, et al. Airways obstruction, chronic expectoration, and rapid decline of $\mathrm{FEV}_{1}$ in smokers are associated with increased levels of sputum neutrophils. Thorax. 1996;51:267-271.

55. Gompertz S, Bayley DL, Hill SL, Stockley RA. Relationship between airway inflammation and the frequency of exacerbations in patients with smoking related COPD. Thorax. 2001;56:36-41.

56. Seemungal TAR, Donaldson GC, Paul EA, Bestall JC, Jeffries DJ, Wedzicha JA. Effect of exacerbation on quality of life in patients with chronic obstructive pulmonary disease. Am J Respir Crit Care Med. 1998;157:1418-1422.

57. Miravitlles M, Ferrer M, Pont A, Zalacain R, Alvarez-Sala JL, Masa F, et al. Effect of exacerbations on quality of life in patients with chronic obstructive pulmonary disease: a 2 year follow up study. Thorax. 2004;59:387-395.
58. Doll H, Miravitlles M. Health-related QOL in acute exacerbations of chronic bronchitis and chronic obstructive pulmonary disease: a review of the literature. Pharmacoeconomics. 2005;23:345-363.

59. Soler-Cataluña JJ, Martínez-García MÁ, Román Sánchez P, Salcedo E, Navarro M, Ochando R. Severe acute exacerbations and mortality in patients with chronic obstructive pulmonary disease. Thorax. 2005; 60:925-931.

60. Miravitlles M, Murio C, Guerrero T, Gisbert R. Pharmacoeconomic evaluation of acute exacerbations of chronic bronchitis and COPD. Chest. 2002;121:1449-1455.

61. Aaron SD, Fergusson D, Marks GB, Suissa S, Vandemheen KL, Doucette $\mathrm{S}$, et al. Counting, analysing and reporting exacerbations of COPD in randomised controlled trials. Thorax. 2008;63:122-128.

62. Vincken W, van Noord JA, Greefhorst APM, Bantje ThA, Kesten S, Korducki L, et al. Improved health outcomes in patients with COPD during 1 yr's treatment with tiotropium. Eur Respir J. 2002;19: 209-216.

63. Brusasco V, Hodder R, Miravitlles M, Korducki L, Towse L, Kesten S. Health outcomes following treatment for six months with once daily tiotropium compared with twice daily salmeterol in patients with COPD. Thorax. 2003;58:399-404.

64. Barr RG, Bourbeau J, Camargo CA, Ram FS. Inhaled tiotropium for stable chronic obstructive pulmonary disease. Cochrane Database Syst Rev. 2005; CD002876.

65. Dusser D, Bravo ML, Iacono P. The effect of tiotropium on exacerbations and airflow in patients with COPD. Eur Respir J. 2006;27: 547-555.

66. Powrie DJ, Wilkinson TM, Donaldson GC, Jones P, Scrine K, Viel K, et al. Effect of tiotropium on sputum and serum inflammatory markers and exacerbations in chronic obstructive pulmonary disease. Eur Respir J. 2007;30:472-478.

67. Niewoehner DE, Rice K, Cote C, Paulson D, Cooper JA Jr, Korducki L, et al. Prevention of exacerbations of chronic obstructive pulmonary disease with tiotropium, a once-daily inhaled anticholinergic bronchodilator: a randomized trial. Ann Intern Med. 2005;143:317-326.

68. Calverley P, Pauwels R, Vestbo J, Jones P, Pride N, Gulsvik A, et al. Combined salmeterol and fluticasone in the treatment of chronic obstructive pulmonary disease: a randomised controlled trial. Lancet. 2003;361:449-456.

69. Casanova C, Cote C, de Torres JP, Aguirre-Jaime A, Marin JM, Pinto-Plata $\mathrm{V}$, et al. The Inspiratory to total lung capacity ratio predicts mortality in patients with COPD. Am J Respir Crit Care Med. 2005;171: 591-597.

70. Celli B, ZuWallack R, Wang S, Kesten S. Improvement in resting inspiratory capacity and hyperinflation with tiotropium in COPD patients with increased static lung volumes. Chest. 2003;124:1743-1748.

71. O’Donnell DE, Flüge T, Gerken F, Hamilton A, Webb K, Aguilaniu B, et al. Effects of tiotropium on lung hyperinflation, dyspnea and exercise tolerance in patients with COPD. Eur Respir J. 2004;23:832-840.

72. Casaburi R, Kukafka D, Cooper CB, Witek TJ Jr, Kesten S. Improvement in exercise tolerance with the combination of tiotropium and pulmonary rehabilitation in patients with COPD. Chest. 2005;127: 809-817.

73. Maltais F, Hamilton A, Marciniuk D, Hernandez P, Sciurba FC, Richter K, et al. Improvements in symptom-limited exercise performance over $8 \mathrm{~h}$ with once-daily tiotropium in patients with COPD. Chest. 2005;128:1168-1178.

74. O'Donnell DE, Sciurba F, Celli B, Mahler DA, Webb KA, Kalberg CJ, et al. Effect of fluticasone propionate/salmeterol on lung hyperinflation and exercise endurance in COPD. Chest. 2006;130:647-656.

75. Casaburi R, Mahler DA, Jones PW, Wanner A, San Pedro G, ZuWallack RL, et al. A long-term evaluation of once-daily inhaled tiotropium in chronic obstructive pulmonary disease. Eur Respir J. 2002;19:217-224

76. Spencer S, Calverley PMA, Burge PS, Jones PW. Health status deterioration in patients with chronic obstructive pulmonary disease. Am J Respir Crit Care Med. 2001;163:122-128. 
77. Singh S, Loke YK, Furberg CD. Inhaled anticholinergics and risk of major adverse cardiovascular events in patients with chronic obstructive pulmonary disease: a systematic review and meta-analysis. JAMA. 2008;300:1439-1450.

78. La Vecchia C, Fabbri LM. Prevention of death in COPD. N EnglJ Med. 2007;356:2211-2212.

79. Calverley PM. Inhaled corticosteroids are beneficial in chronic obstructive disease. Am J Respir Crit Care Med. 2000;161:341-342.

80. Barnes PJ. Inhaled corticosteroids are not beneficial in chronic obstructive pulmonary disease. Am J Respir Crit Care Med. 2000;161:342-344.

81. Kesten S, Jara M, Wentworth C, Lanes S. Pooled clinical trial analysis of tiotropium safety. Chest. 2006;130:1695-1703.
82. Ernst $\mathrm{P}$, Gonzalez AV, Brassard P, Suissa S. Inhaled corticosteroid use in chronic obstructive pulmonary disease and the risk of hospitalization for pneumonia. Am J Respir Crit Care Med. 2007;176:162-166.

83. Wedzicha JA, Calverley PM, Seemungal TA, Hagan G, Ansari Z, Stockley RA. The prevention of chronic obstructive pulmonary disease exacerbations by salmeterol/fluticasone propionate or tiotropium bromide. Am J Respir Crit Care Med 2008;177:19-26.

84. Quanjer PH. Standardised lung function testing of the European Community for Coal and Steel. Bull Eur Physiopathol Respir. 1983; 19:7-10.

International Journal of COPD

\section{Publish your work in this journal}

The International Journal of COPD is an international, peer-reviewed journal of therapeutics and pharmacology focusing on concise rapid reporting of clinical studies and reviews in COPD. Special focus is given to the pathophysiological processes underlying the disease, intervention programs, patient focused education, and self management protocols.

\section{Dovepress}

This journal is indexed on PubMed Central, MedLine and CAS. The manuscript management system is completely online and includes a very quick and fair peer-review system, which is all easy to use. Visit http://www.dovepress.com/testimonials.php to read real quotes from published authors.

Submit your manuscript here: http://www.dovepress.com/international-journal-of-copd-journal 